\title{
CREMATION AS LIMITATION? A PALEODEMOGRAPHIC INQUIRY INTO THE ACCURACY OF MACROSCOPIC ANALYSIS OF CREMATED HUMAN REMAINS BASED ON AN EAST LITHUANIAN SAMPLE
}

\author{
LAURYNAS KuRILA
}

Lithuanian Institute of History, Department of Archaeology, Lithuania

\begin{abstract}
Capabilities of skeletal anthropology are limited when studying cremations. The paper assesses the pattern of these limitations and the probability of bias in the macroscopic analysis of cremated remains with an emphasis on its aspects in need of special attention. Biased analysis is viewed as a hazard not only to bioarchaeology, but also to a broad scale of topics in the archaeology of burial. As a methodological approach, a comparative paleodemographic inquiry is proposed. It parallels inhumation $(n=72)$ and cremation $(n=370)$ samples from the $3 \mathrm{rd} / 4$ th -11 th/12th centuries AD of East Lithuania. Life tables are created and mortality and reproductive profiles are calculated. Even though the analysed cremated bone material is fragmentary, a rather high correspondance of the profiles is registered, except for several aspects. Significant difference between inhumations and cremations is the lower subadult ratio in the latter. Under-estimation of infants and young children distorts newborn life expectancy and reproductive profiles. Another ground for bias occurs in the probable identification of adolescents as adults when aging cremations. The third risk of bias, alghough somewhat obscure, is observed in aging adults related to the sex of the deceased. Differences of male and female mortality profiles between the samples suggest that the biases in aging and sexing cremated adults are inter-related.
\end{abstract}

Keywords: cremation, age at death estimation, sex determination, paleodemography, reliability of macroscopic analysis, East Lithuanian barrows 


\section{INTRODUCTION}

Past populations have practiced many forms of diposal of the dead which some present-day archaeologists and skeletal anthropologists would probably fancy had never been in use. Some prehistorians see such burial rites as cremation, scattering of the remains, reburial, etc. as an exciting subject for research, while others would rather view them as an obstacle on the way of studying human biological past. Cremation, aside from those disposal forms which left completely no bodies, is the most destructive for human remains. However, it had been in wide use, and scientists have to include cremains into their research unless they are determined to accept the fact of losing a large part of their data.

There is a considerable number of inquiries into cremation $[16,18,19,27$, $39,46,53]$, but, despite rather good knowledge of how fire affects bone [11, 19, $21,26,47,50,51]$, there is still a lack of awareness of how it impacts our studies in archaeology of burial. In other words, mere description of such processes as shrinkage, warping, or microstructure changes of cremains does not guarantee a solid basis for relevant employment of the material into scientific circulation. This should be especially said by archaeologists who have no physical-anthropological training and who feel a demand for specialized methodology-based or comparative studies to rely on (e.g. for a reliability of osteological sexing of cremated remains see $[20,22,32])$.

Most of archaeologists would not question that research of cremated burial populations is much more challenging than that of uncremated ones. Also, it is needless to argue that past skeletal samples are biased [28]. But the degree to which cremation is responsible for the bias is more a matter of personal comprehension. There are examples of assays in archaeology which make little difference between uncremated and cremated osteological material as well as of those which reject the latter as of insufficient scientific value. A simple error (or higher probablility of error in a sample) in aging or sexing a burial might start a chain reaction of erroneous inferences in the studies into lifestyles or social structures of past populations. For example, longer estimated ages at death result in the larger population size, which suggests a more complex settlement pattern. Another example, the interest of gender archaeology in cross-dressing (burial of biological females with masculine grave goods and vice versa) appeals largely to osteological sex determination [3, 36, 49], and within this research programme, the need for correct sexing is crucial. Archaeology must thus seek for methodological and theoretical approaches to cope with databased problems, and this, first of all, requires finding a means to highlight and assess the factors that cause risk of distortion of the data. 
This paper attempts to evaluate the impact of cremation - not the physical damage that human remains suffer in funeral pyre, but the way the very phenomenon of cremation practices in past societies may have influenced the cognitive capabilities of archaeology. A comparative paleodemographic case study is presented to meet this aim. Calculation of various demographic profiles for uncremated and cremated bone samples is applied to disclose aspects of burial archaeology that require special delicacy when dealing with cremated burial populations. Such inquiry is expected to serve aptly to demonstrate a probable bias of the results of osteological analysis, since it is less dependent on the archaeological context than are interpretative theory-based studies, e.g. association of grave good sets of grave constructions to biological age. As the database, the bone collection from the Roman Period - Early Medieval East Lithuania is employed.

The paper does not aim at presenting a paleodemographic study of East Lithuanian population based on the osteometric analysis of fragmentary cremated skeletal collection. No preconception is made that the data are utterly reliable for that. The goal is, applying paleodemography as a tool, to test the capabilities of osteometric techniques for the above-mentioned material, which is in its physical charasteristics rather representative for all East Baltic cremations. Also, the expected results are answers to the questions commonly given by archaeologists to physical anthropologists of whether or not cremations can be properly employed in their studies and what the main dangers in so doing are.

Paleodemographic studies of contemporaneaus East Baltic populations $[2,24,29,44,61]$ are still rare and insufficient. Due to the lack of research, comparative inter-regional analysis is not promising. To yield the best results, burials from the same region and contigous chronological stages are operated. Although the chronological range of the burials is as wide as $800-1000$ years (3rd/4th - 11th/12th centuries), moderately stable cultural milieu throughout the period is observed in archaeological record. The shift from inhumation to cremation took place in late 4 th - early 6th centuries in Eastern Lithuania, thereby there had been a period over a century long of coexistance of both burial forms. Changes in burial practices, barrow constructions, and grave good assemblages were graduate. Settlement patterns, too, do not attest to any large-scale migration, changes in economy or lifestyle which could have influenced the demographic profiles. This allows one to expect the manner of burial to be the main, if not the only, agent affecting the results of osteological analysis. 


\section{MATERIAL AND METHODS}

To assess the inequality between informativeness of unburnt and of cremated human osteological material, the database was built which includes macroscopically analysed burials from 69 excavated East Lithuanian barrow and flat cemeteries (Figure 1). The collection, the major part of which is currently being stored at the depository of the Department of Anatomy, Histology and Anthropology, Faculty of Medicine, Vilnius University, consists of 72 inhumations and 370 cremations. The remains of 78 individuals were identified in the former, and the minimum number of 454 individuals in the latter. The available material does not consist of any regular population larger than 11 inhumed individuals and 60 cremated ones. Thus it is theoretical populations that are operated in this paper. This methodological approach may be challenging. On the other hand, it also has its avdantages, as it minimizes the probablility of the bias related to different post-depositional processes, the destruction of the cemeteries, excavation techniques, etc. The relevance or the collection for research has been proved by the study of social organisation in the region [31].

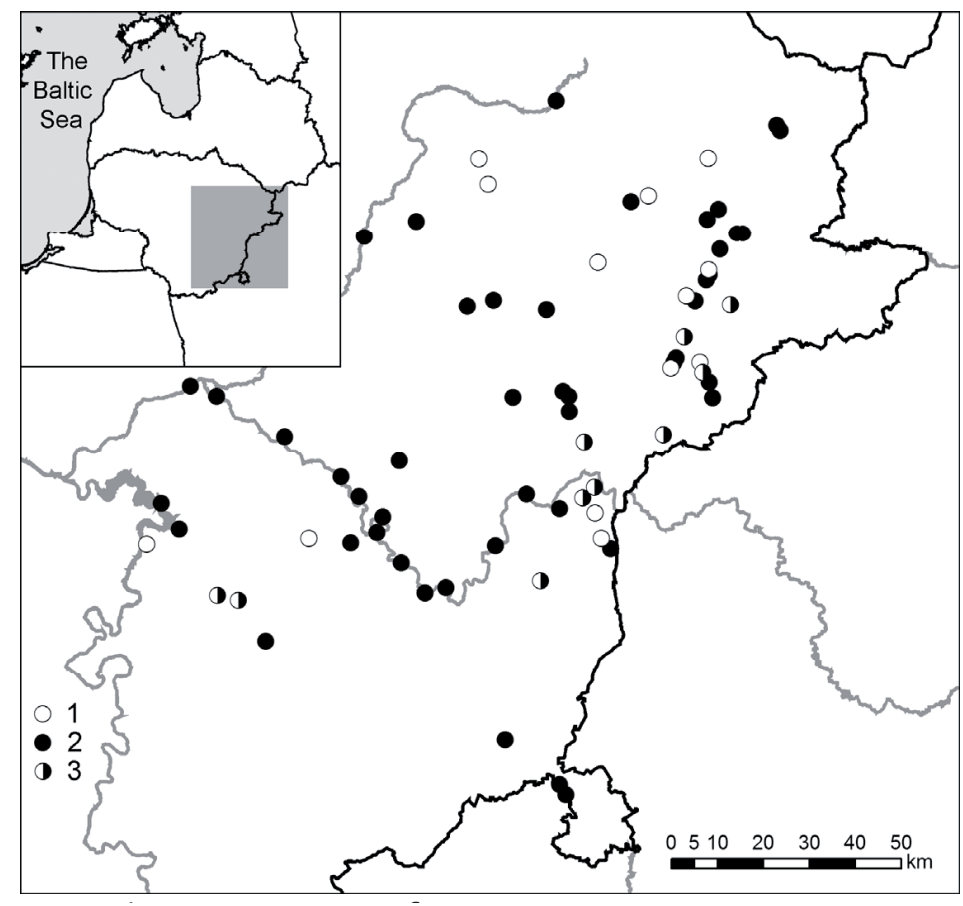

Figure 1. Locations of cemeteries employed in the study (1 - inhumations, 2 - cremations, 3 - inhumations and cremations). 
The inhumations had been analysed by Prof. Gintautas Česnys and Prof. Rimantas Jankauskas. The age at death and sex determinants were taken for this study from their multiple publications and unpublished accounts. Although the osteological material is of varying degrees of preservation, the reliability of age at death estimation and sex determination is unlikely to be lower than that reported by most skeletal anthropologists [14, 17, 37, 38, 40, 41].

The osteological analysis of most of the cremations was made by Prof. Jankauskas and the author of the present paper. It was based on the macroscopic examination and measurements of the bones in line with the standards $[18,55]$ while taking into consideration bone deformations, warping, and shrinkage. It should be noted that most of the burials were incomplete, the average weight of bones was 419 grams per burial, or 341 grams per individual, which is only about $10-20$ percent of an average cremated adult body $[6,54$, 57]. The state of preservation of the bones (Figures 2, 3) is rather low in most of the burials. They are heavily effected by high temperature (up to $800{ }^{\circ} \mathrm{C}$ ), and their deliberate crumbling after the cremation also seems very probable. On the other hand, this property of the collection enhances its suitability within the framework of the present study, as it represents most of prehistoric cremations.

For cremations, the minimum number of individuals was determined on the basis of duplication of single and paired bones: the petrous pyramids of the temporals, the frontal, the occipital, the maxilla and the mandible, the odontoid process of the axis, some of the long bones, etc. In some cases, unduplicated bones from individuals of obviously different sex or age at death also indicated double or group burials.

Sex determination was attempted only for adults of over 20 years of age, and in only several cases for younger individuals. The main criteria were the cranial bones: supraorbital ridge of the frontal, the temporals, the zygomatics, the occipital, the maxilla, and the mandible [10]. Measurements were also made of the fragments of the mandible, the temporals, the zygomatics, the frontal, the vault wall, the odontoid process of the axis, the glenoid fossa of the scapulae, and the epiphyses and diaphyses of the femur, the humerus, the radius, and other long bones. Visual evaluation of general robusticity of the bones was used as subsidiary criteria in isolated cases. Pelvic sex determination was unavailable due to complete crumbling of the bone. The sexing procedure failed to conclude equally securely, therefore the individuals were divided into five sex categories: male, probable male, unsexed, probable female, and female $\left(\widehat{\partial}, \partial^{\lambda} ?, ?, q ?\right.$, ? $)$. 


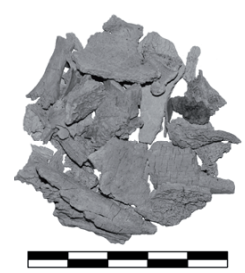

Figure 2. Cremated bones from Paduobè, Šaltaliūnè III barrow cemetery, barrow 2, burial 4 (unsexed adult, 20-40). Photo by the author.

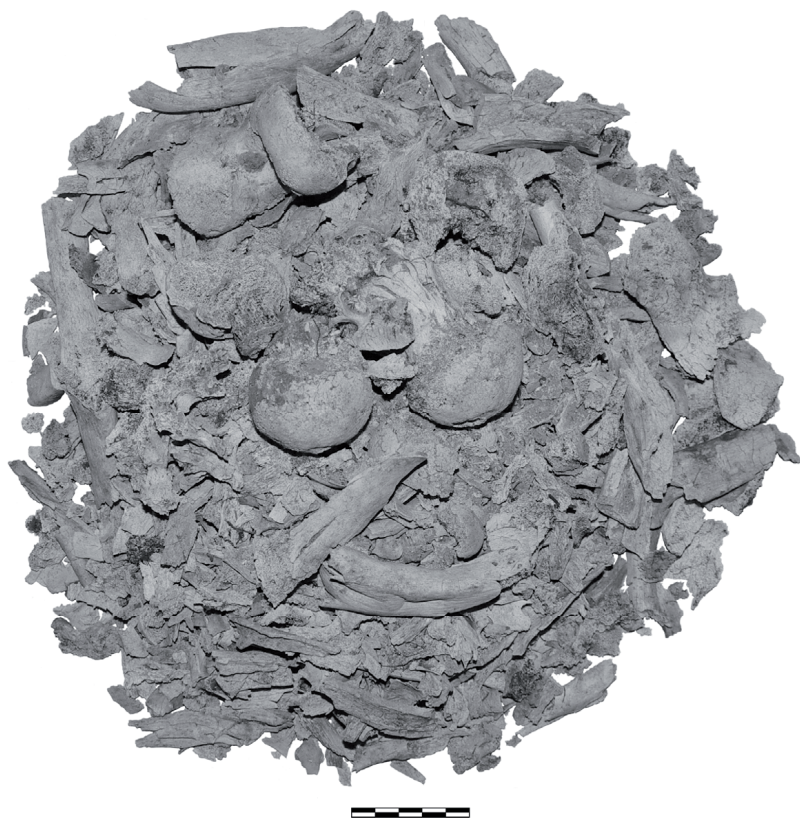

Figure 3. Cremated bones from Santaka barrow cemetery, barrow 4, burial 2 (male, $>40$ ). Photo by the author.

For the age at death estimation, the examination of the scale of cranial suture closure [10, 40,52], dental formation and eruption [9, 43, 52], epiphyseal fusion of the long bones $[9,60]$, and vertebral growth and osteophyte development [48] were applied. Aging with a satisfactory degree of precision was mostly possible for subadults and far more seldom for adults. The average estimated age interval was as wide as 18.3 years (a relative top margin of 60 years was set for the intervals without a determined one). For this latter reason, rather wide age groups were further operated: $<1,1-4,5-11,12-19,20-39$, and $\geq 40$ years. The probable numbers of individuals were calculated for the age groups, which were applied in the life tables. The algorithm for this procedure involved subsuming the determined individual age intervals to the age groups (e.g. a 30-50 interval falls into two last age groups with equal probability), and 
then indexation of the obtained figures by the probability coefficient assessed on the basis of the minimum numbers of individuals in age groups (a statistical individual' with the above-mentioned age interval, would be subdivided for the $20-39$ and $\geq 40$ age groups as 0.72 and 0.28 , respectively).

The inhumations were divided into the same sex categories and age groups using the same algorithm for calculation of probable numbers of individuals. Life tables were then created for inhumations and cremations after the model of Acsádi and Nemeskéri [1] (Tables 1,2). Since the numbers of infants and young children appeared to be improbable for a prehistoric burial population, attempts were made to simulate them by increasing to a presumably correct level: the number of newborns to the one registered in the well-excavated Plinkaigalis flat cemetery (Central Lithuania, 5th-6th centuries) $-\mathrm{d}_{<1}=24.25$ [13]; and the overall number of young children accordingly to the study by Rösing and Jankauskas [42] which was based on a large Lithuanian skeletal sample $-\mathrm{d}_{<5}=45.2$. All demographic profiles were calculated paralleling the cremations to the inhumations: newborn life expectancy after Acsádi and Nemeskéri [1] and Boquet-Appel and Masset [8], adult life expectancies for males and females after Acsádi and Nemeskéri [1], reproductive profiles after Henneberg [25], a modelled population size after Ubelaker [52], and other figures. The total fertility value $\left(U_{c}=7.45\right)$ was adopted from Lorimer [34].

Table 1. Life table after Acsádi and Nemeskéri [1] (inhumations)

\begin{tabular}{lccccccc}
\hline \multicolumn{1}{c}{$\boldsymbol{x}$} & $D_{x}$ & \multicolumn{1}{c}{$\boldsymbol{d}_{\boldsymbol{x}}$} & \multicolumn{1}{c}{$\boldsymbol{I}_{\boldsymbol{x}}$} & \multicolumn{1}{c}{$\boldsymbol{q}_{x}$} & \multicolumn{1}{c}{$L_{x}$} & $T_{x}$ & $\boldsymbol{e}^{0}{ }_{x}$ \\
\hline$<1$ & 3.20 & 4.10 & 100.00 & 0.04 & 97.95 & 2461.76 & 24.62 \\
\hline $1-4$ & 12.31 & 15.78 & 95.90 & 0.16 & 352.02 & 2363.81 & 24.65 \\
\hline $5-11$ & 10.74 & 13.77 & 80.12 & 0.17 & 512.59 & 2011.79 & 25.11 \\
\hline $12-19$ & 8.30 & 10.65 & 66.34 & 0.16 & 488.14 & 1499.19 & 22.60 \\
\hline $20-39$ & 25.73 & 32.99 & 55.69 & 0.59 & 784.00 & 1011.05 & 18.15 \\
\hline$\geq 40$ & 17.71 & 22.71 & 22.71 & 1.00 & 227.05 & 227.05 & 10.00 \\
\hline & 78.00 & 100.00 & & & 2461.76 & & \\
\hline
\end{tabular}


Table 2. Life table after Acsádi and Nemeskéri [1] (cremations)

\begin{tabular}{lrrrrrrl}
\hline \multicolumn{1}{c}{$\boldsymbol{x}$} & \multicolumn{1}{c}{$D_{x}$} & \multicolumn{1}{c}{$\boldsymbol{d}_{x}$} & \multicolumn{1}{c}{$\boldsymbol{I}_{x}$} & \multicolumn{1}{c}{$\boldsymbol{q}_{x}$} & \multicolumn{1}{c}{$L_{x}$} & $T_{x}$ & $\boldsymbol{e}^{0}$ \\
\hline$<1$ & 5.50 & 1.21 & 100.00 & 0.01 & 99.39 & 2918.38 & 29.18 \\
\hline $1-4$ & 29.78 & 6.56 & 98.79 & 0.07 & 382.03 & 2818.99 & 28.54 \\
\hline $5-11$ & 46.41 & 10.22 & 92.23 & 0.11 & 609.82 & 2436.96 & 26.42 \\
\hline $12-19$ & 18.93 & 4.17 & 82.01 & 0.05 & 639.37 & 1827.14 & 22.28 \\
\hline $20-39$ & 260.44 & 57.37 & 77.84 & 0.74 & 983.07 & 1187.77 & 15.26 \\
\hline$\geq 40$ & 92.94 & 20.47 & 20.47 & 1.00 & 204.71 & 204.71 & 10.00 \\
\hline & 454.00 & 100.00 & & & 2918.38 & &
\end{tabular}

One-tailed unpaired t-tests and two sample t-tests between percents were performed to evaluate the significance of differences between inhumations and cremations for some profiles. They were considered to differ significantly at $p$ values of $<0.05$.

\section{RESULTS AND DISCUSSION}

The obtained demographic profiles and some other figures are given in Table 3. The most noticeable and statistically highly significant discrepancy between the two samples is the number of subadult individuals $\left(d_{<20}\right)$ which is twice larger in inhumations -44.31 vs. $22.16 \%(p=0.0000)$. This is characteristic of all subadult age groups (Figure 4, Tables 1,2). The largest distances are observed in the $<1,1-4$, and $12-19$ age groups, while in the 5-11 age group the distance is smaller. This can be explained through the very nature of the skeletal material. Infant and young children bones and deciduous teeth are very fragile and less resistant to high temperature. Small fragments of unfused epiphyses and diaphyses which are identified among cremains cannot always aid as proper criteria. The probablility of remaining unnoticed when analysing cremations is higher for young children remains than for those of older children, especially in group burials. Adolescent $\left(\mathrm{d}_{12-19}\right)$ identification is in most of the cases based on epiphyseal fusion which occurs at different ages in different parts of the skeleton $[9,60]$. Cremations, however, do not always provide a possibility to identify particular growth plates and to achieve more than rough division of the individuals into subadults and adults. 


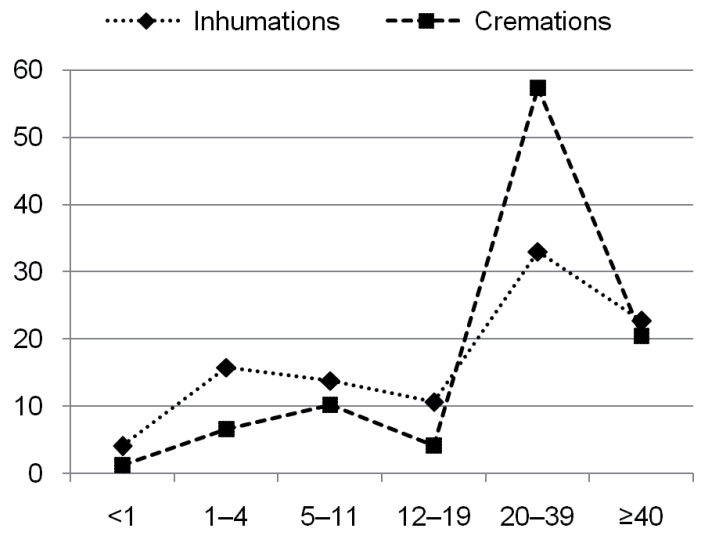

Figure 4. The numbers of individuals in age groups $\left(d_{x}\right)$.

Table 3. Demographic profiles for inhumations and cremations

\begin{tabular}{|c|c|c|c|}
\hline Demographic profiles & Inhumations & Cremations & $p$ value \\
\hline Number of individuals & 78 & 454 & \\
\hline Average estimated age at death interval (years) & 12.01 & 18.32 & \\
\hline $\begin{array}{l}\text { Average middle point of estimated age at death } \\
\text { interval (years) }\end{array}$ & 26.03 & 29.45 & 0.0494 \\
\hline Proportion of subadults $\left(\mathrm{d}_{<20}, \%\right)$ & 44.31 & 22.16 & 0.0000 \\
\hline Proportion of subadults $\left(\mathrm{d}_{<20}, \%\right), \mathrm{d}_{<1}=24.25$ & 56.00 & 40.31 & \\
\hline $\begin{array}{l}\text { Proportion of subadults }\left(d_{<20}, \%\right), d_{<1}=24.25 \text {, } \\
d_{<5}=45.20\end{array}$ & 61.90 & 53.75 & \\
\hline $\begin{array}{l}\text { Newborn life expectancy }\left(\mathrm{e}^{0}{ }_{0}\right) \text { after Acsádi and } \\
\text { Nemeskéri [1] }\end{array}$ & 24.62 & 29.18 & \\
\hline $\begin{array}{l}\text { Newborn life expectancy }\left(\mathrm{e}^{0}\right) \text { after Acsádi and } \\
\text { Nemeskéri [1], } \mathrm{d}_{<1}=24.25\end{array}$ & 19.55 & 22.50 & \\
\hline $\begin{array}{l}\text { Newborn life expectancy }\left(\mathrm{e}^{0}{ }_{0}\right) \text { after Acsádi and } \\
\text { Nemeskéri }[1], \mathrm{d}_{<1}=24.25, \mathrm{~d}_{<5}=45.20\end{array}$ & 17.25 & 17.97 & \\
\hline $\begin{array}{l}\text { Newborn life expectancy }\left(\mathrm{e}^{0} 0\right) \text { after Boquet-Appel } \\
\text { and Masset [8] }\end{array}$ & 16.15 & 28.88 & \\
\hline $\begin{array}{l}\text { Juvenility index (5-14/ } \geq 20) \text { after Boquet-Appel } \\
\text { and Masset [8] }\end{array}$ & 0.32 & 0.15 & \\
\hline Proportion of unsexed adults (\% of all adults) & 14.29 & 30.75 & 0.0178 \\
\hline $\begin{array}{l}\text { Proportion of sexed adults (\% of the whole } \\
\text { sample) }\end{array}$ & 53.85 & 51.10 & 0.6537 \\
\hline
\end{tabular}




\begin{tabular}{|c|c|c|c|}
\hline Demographic profiles & Inhumations & Cremations & $p$ value \\
\hline Masculinity index: $\delta / q$ & 1.12 & 1.07 & 0.9060 \\
\hline Masculinity index: $(\widehat{\jmath}+\widehat{\jmath} ?) /(q+q ?)$ & 0.91 & 0.92 & 0.9791 \\
\hline Life expectancy at adulthood $\left(\mathrm{e}^{0}{ }_{20}\right)$, males $\left({ }^{\lambda}\right)$ & 16.35 & 17.80 & \\
\hline Life expectancy at adulthood $\left(\mathrm{e}^{0}{ }_{20}\right)$, females ( $(+)$ & 17.06 & 13.75 & \\
\hline Life expectancy at adulthood $\left(\mathrm{e}^{0} 20\right)$, males $\left(\hat{\partial}+\widehat{\partial}^{\lambda}\right.$ ) & 16.43 & 17.47 & \\
\hline $\begin{array}{l}\text { Life expectancy at adulthood }\left(\mathrm{e}^{0}{ }_{20}\right) \text {, females } \\
\left(q_{+}+q_{?}\right)\end{array}$ & 17.04 & 13.49 & \\
\hline $\begin{array}{l}\text { Average middle point of age interval (years), } \\
\text { all adults }\end{array}$ & 36.44 & 36.72 & 0.4773 \\
\hline $\begin{array}{l}\text { Average middle point of age interval (years), } \\
\text { adult females (ㅇ) }\end{array}$ & 36.71 & 35.31 & 0.3332 \\
\hline $\begin{array}{l}\text { Average middle point of age interval (years), } \\
\text { adult males }\left(\hat{\delta}+\delta^{\lambda} ?\right)\end{array}$ & 34.98 & 38.53 & 0.0836 \\
\hline $\begin{array}{l}\text { Average middle point of age interval (years), } \\
\text { adult females }(+++?)\end{array}$ & 35.73 & 34.25 & 0.2999 \\
\hline $\begin{array}{l}\text { Masculinity index: } 20-39 \text { age group }\left(\hat{\partial}+\delta^{\top} ?\right) / \\
(q++?)\end{array}$ & 1.09 & 0.76 & \\
\hline Masculinity index: $\geq 40$ age group $\left(\delta^{\lambda}+\delta^{\Uparrow}\right) /(++q$ ? $)$ & 0.86 & 2.11 & \\
\hline $\begin{array}{l}\text { Potential gross reproduction rate }\left(\mathrm{R}_{\text {pot }}\right) \text { after } \\
\text { Henneberg }[25]\end{array}$ & 0.65 & 0.63 & \\
\hline $\begin{array}{l}\text { Net reproduction rate }\left(\mathrm{R}_{0}\right) \text { after Henneberg [25], } \\
\mathrm{U}_{c}=7.45\end{array}$ & 1.50 & 1.90 & \\
\hline $\begin{array}{l}\text { Net reproduction rate }\left(R_{0}\right) \text { after Henneberg [25], } \\
U_{c}=7.45, d_{<1}=24.25\end{array}$ & 1.19 & 1.45 & \\
\hline $\begin{array}{l}\text { Net reproduction rate }\left(\mathrm{R}_{0}\right) \text { after Henneberg [25], } \\
\mathrm{U}_{c}=7.45, \mathrm{~d}_{<5}=45.20\end{array}$ & 1.03 & 1.13 & \\
\hline $\begin{array}{l}\text { Mean number of births per female }(C) \text { after } \\
\text { Henneberg [25] }\end{array}$ & 11.18 & 14.12 & \\
\hline $\begin{array}{l}\text { Mean number of births per female }(C) \text { after } \\
\text { Henneberg }[25], d_{<5}=45.20\end{array}$ & 7.65 & 8.39 & \\
\hline Crude mortality rate $(\mathrm{M}, \% \mathrm{o})$ & 40.62 & 34.27 & \\
\hline Crude mortality rate $(\mathrm{M}, \% \mathrm{o}), \mathrm{d}_{<1}=24.25$ & 51.15 & 44.45 & \\
\hline Crude mortality rate $(M, \% o), d_{<1}=24.25, d_{<5}=45.20$ & 57.96 & 55.65 & \\
\hline Population size $(\mathrm{P})$ after Ubelaker [52], N=30, $\mathrm{T}=100$ & 7.39 & 8.76 & \\
\hline
\end{tabular}


Dissimilar numbers of subadults underlie differences in calculated newborn life expectancies $\left(\mathrm{e}^{0}{ }_{0}\right)$, especially when applying the formula by Boquet-Appel and Masset [8] which uses the juvenility index as its key variable and which is therefore differently sensitive to under-estimation of subadults. To assess the impact of subadult deficit in cremations, an attemt was also made to compare the means of individual ages at death in the two samples (middle points of age intervals were applied as individual ages at death). This test demonstrated significant difference $(p=0.0494)$. Errors in identification of subadults also engender sharp disparities in all reproduction profiles (see below).

Leaving aside recurring debates on the cultural or taphonomic factors which can contribute to subadult deficit in burial sites $[5,12,23,30,33,35$, 45], one can argue that, from this point of view, cremations should be subject to a much more careful assessment. When operating any results of an osteological analysis, there is a demand for relevant modeling of the subadult segment in the studied burial population. Employing uncorrected figures can cause critical distortions of the results.

Among the identified adults, the most significant $(p=0.0103)$ difference is that between the proportions of vain attempts of sex determination. As many as for $30.75 \%$ of the identified adults the sexing procedure failed in the cremations, i.e. twice more than in the inhumations. On the other hand, this may probably not only indicate complicated sex determination for cremations, but also once again advert to the problem of aging. The percentage of sexed adults is nearly equal in both samples. It can thus be argued that some of the identified adults unascribed to either of the sexes in the cremations may actually be over-aged adolescents.

Differences in the numbers of the identified males and females (masculinity indexes) are insignificant. More intriguing is the trend, observed equally in both samples, of increased proportions of females when the individuals sexed as probable males and probable females are included. This prompts possibly similar analysis errors: higher probability for male adolescents to be aged as adults than for female ones; sexing of some females as males; sexing of some males or adolescents as probable females; too frequent attribution of sexed females to probable female category; etc. Even though none of the figures for masculinity indexes differs significantly from either each other or the theoretically neutral figure of 1 , this trend should not be lost of sight in the studies which require precise sex determination, and especially in those based on the data of isolated burials instead of large skeletal series. In archaeological studies, as a methodological alternative or supplementary argumentation, 
grave good evaluation should not be disregarded to provide clues about the sex of the deceased, despite scepticism towards this approach advocated by some researchers $[4,15,58]$.

The life expectancies of adult males and females differ rather clearly between inhumation and cremation samples. Although the differences in the averages of the estimated individual ages at death are not statistically significant, both these numbers and the life expectancy at adulthood $\left(e^{0}{ }_{20}\right)$ values deserve consideration. Firstly, all figures suggest longer life expectancy for males than that for females in cremations, and vice versa in inhumations. Secondly, male life expectancies are higher in cremations than in inhumations, and just the opposite for females. Whether or not the individuals whose sex was identified as probable were included into the calculations, is a factor with very little impact on the results. A similar tendency is also evidenced by masculinity indexes if they are calculated separately for the $20-39$ and $\geq 40$ age groups, although the datasets are too small for a reliable statistics in both cases. This once again prompts the problem of probable false identification of some cremated adolescent remains as (young?) adult females.

Interestingly, the data of namely cremations, not inhumations, correspond to the trend of shorter female lifespan observed in most of preindustrial societies in the East Baltic region [24, 29, 62] and elsewhere [7, 59]. But upon further inspection, both inhumations and cremations display generally similar mortality trends: higher mortality rates for younger adult females, i.e. those exposed to risks related to childbirth, and higher mortality of males in older adult age group (Figures 5, 6). This latter fact alone, however, is not a satisfactory argument to deny possible errors in aging or sexing. At the present stage, the study of the East Lithuanian skeletal data encourages one to argue that sexing and/or aging cremations are prone to bias. The degree and even the direction of bias in age at death estimation are likely to be sex-dependant. Vice versa, false sex determinations may be related to poor bone preservation and age, as demonstrated by other inquiries [56].

The reproductive profiles show higher fertility rates for cremations and higher probability for the population to remain stable, i.e. for the offspring generation to replace the parental one. Even more so, employing original values of subadult proportions, the net reproduction rate $\left(R_{0}\right)$ suggests remarkable population growth. It can be argued that under-estimation of subadults is the main, and probably the only, cause for this. Only when the $\mathrm{d}_{\leq 15}$ value is increased by $20.79 \%$ (from $37.65 \%$ to $58.44 \%$ ) in inhumations or by $38 \%$ (from $19.56 \%$ to $57.56 \%$ ) in cremations, $\mathrm{R}_{0}$ would be equal to the theoretical stationary value of 1 , which should seem likely if the archaeological background 
and wide chronology of the data is taken into account. If applying the $d_{<5}$ value of 45.2 proposed by Rösing and Jankauskas [42], the population appears almost stable as reflected in inhumations and moderately growing in cremations. These latter results once more evidence the need for artificial increase of subadult ratio and the validity of the above-mentioned value.

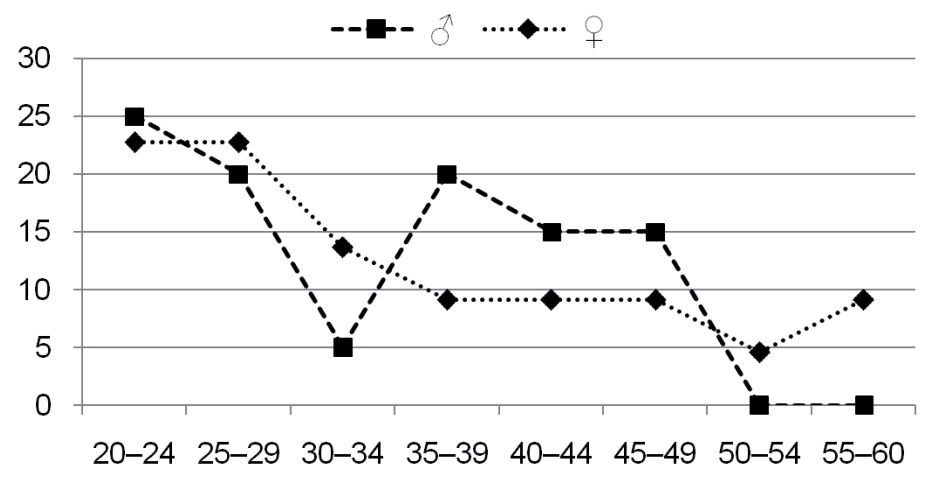

Figure 5. The numbers of adult males and females in age groups in percent (averages of the estimated individual ages): inhumations.

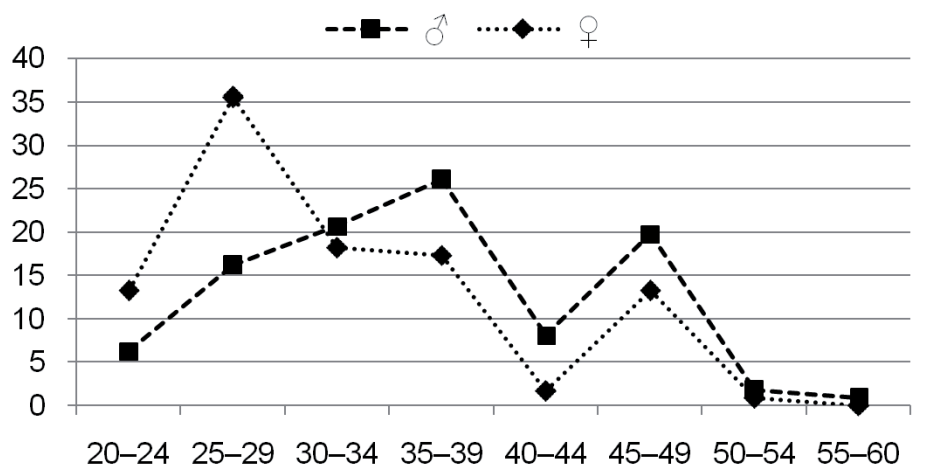

Figure 6. The numbers of adult males and females in age groups in percent (averages of the estimated individual ages): cremations.

Crude mortality rate is also reliant on to what, if any, degree the subadult ratio is simulated. The data of inhumations and cremations do not depart enough to indicate a bias more extensive than the one which rests on the selection of simulation strategy. No significant difference is observed between the calculated population sizes either. If the modelled subadult ratio is applied, it decreases 
to a minimal level and has no effect on social interpretation of the cemetery. Such a tenuous bias tends to be marginal in majority of the cases compared to that caused by factors independent from osteological techniques or applied paleodemographic methodologies: probability of the whole once living population to be buried in one disposal area, disturbance of the cemetery, its coverage by the excavations, accuracy of dating, etc.

\section{CONCLUSIONS}

Among the great many means available to approach the problem of reliability of the cremated human bone data, a paleodemographic inquiry is proposed in this paper. It may test their value not for paleodemography alone, though, but also for the research of social organizations, gender relations, and other topics which can benefit from studying burials. The characteristics of the employed database, i.e. generally rather low state of preservation and paucity of the cremains, allows one to expect a larger bias in osteological analysis, but on the other hand, its better correspondance to that expected in most of cremated skeletal samples from archaeological contexts. In other words, the target of the study (macroscopic analysis of poorly preserved cremains) is exactly what is usually operated in numerous and multiform case-studies. There are of course factors which were left outside the scope of the paper, but which can probably affect the results, e.g. probability for an unrelated bone to be accidently included in the burial when collecting the remains from a repeatedly used pyre, or probability of disturbed and commingled burials to be identified as group ones.

One significant limitation of cremated burials is the deficit of the identified subadults. In the present paleodemographic study, it is the major agent responsible for the bias in some profiles. It would undoubtedly have a similarly negative impact in research of other topics, e.g. social dimensions of burial practices or family structures. Therefore the demand for apt models of actual subadult mortality is crucial. It can be argued, judging from the obtained reproduction profiles, that the $\mathrm{d}_{<5}$ value of 45.2 proposed by Rösing and Jankauskas [42] is very likely to be close to reality. Another point where the risk of under-estimation occurs is in the adolescent age group. Some of the adolescent individuals may be over-aged and identified as adults.

Sex determination procedure for cremations does not seem to suffer from large-scale systematic bias. If it exists, it is more likely to affect inhumations and cremations alike. Its exact pattern and direction is vague, but there is a 
good reason to assume that biased sex ratio may partly be an outcome of the above-mentioned under-estimation of adolescents, too. An important aspect of aging and sexing adults also is the subtle link between these two analysis procedures. That the bias in aging cremations might be related to the sex of the deceased and probably vice versa, can be inferred from the observed differences, although tenuous, of male and female mortality figures between inhumation and cremation samples.

The present study demonstrates, one would probably even find this surprising, that many figures display rather close match between inhumation and cremation samples. This encourages one to qualify cremated human bone data as of not lesser value than that of unburt bone, regardless of manifest differences in physical condition of the remains and availability of criteria for the analysis. The degree of accuracy of macroscopic analysis can be sufficient for various topics of research even if not more than fragmentary cremated human remains are available for the study.

\section{ACKNOWLEDGEMENTS}

The author is grateful to Prof. Rimantas Jankauskas for his invaluable assistance in creating the database, kind permission to use the unpublished data, and professional advice.

\section{REFERENCES}

1. Acsádi G., Nemeskéri J. (1970). History of human life span and mortality. Akadémiai Kiadó, Budapest.

2. Allmäe R. (2014). The demography of Iron Age graves in Estonia. Lietuvos archeologija, 40, 163-179.

3. Arnold B. (2002). "Sein und Werden": Gender as Process in Mortuary Ritual. In: Nelson S.M., Rosen-Ayalon M. (eds.). In Pursuit of Gender: Worldwide Archaeological Approaches. AltaMira Press, Walnut Creek, 239-256.

4. Arnold B. (2006). Gender and Archaeological Mortuary Analysis. In: Nelson S.M. (ed.). Handbook of Gender in Archaeology. AltaMira Press, Lanham, 137-170.

5. Barker B.J., Dupras T.L., Tocheri M.W. (2005). The Osteology of Infants and Children. Texas A\&M University, College Station.

6. Bass W.M., Jantz R.L. (2004). Cremation Weights in East Tennessee. Journal of Forensic Sciences, 49, 901-904. 
7. Berin B.N., Stolnitz G.J., Tenenbein A. (1989). Mortality trends of males and females over the ages. Transactions of Society of Actuaries, 41, 9-31.

8. Bocquet-Appel J.P., Masset C. (1982). Farewell to Paleodemography. Journal of Human Evolution, 11, 321-333.

9. Brothwell D.R. (1981). Digging up bones: The excavation, treatment and study of human skeletal remains. 3rd ed. Cornell University Press, Ithaca, New York.

10. Buikstra J.E., Ubelaker D.H. (eds.) (1994). Standards for Data Collection from Human Skeletal Remains. Proceedings of a Seminar at The Field Museum of Natural History Organized by Jonathan Haas (=Arkansas Archeological Survey Research Series, 44). Arkansas Archeological Survey, Fayetteville.

11. Castillo R.F., Ubelaker D.H., Acosta J.A.L., de la Fuente G.A.C. (2012). Effects of temperature on bone tissue. Histological study of the changes in the bone matrix. Forensic Science International, 226, 33-37.

12. Chamberlain A. (2000). Minor concerns: a demographic perspective on children in past societies. In: Sofaer Derevenski J. (ed.). Children and Material Culture. Routledge, London, New York, 206-212.

13. Česnys G. (1987). Palaeodemography of Iron Age man in Lithuania. Historická demografie, 11, 9-20.

14. Đurić M., Rakočević Z., Đonić D. (2005). The reliability of sex determination of skeletons from forensic context in the Balkans. Forensic Science International, 147, 159-164.

15. Effros B. (2000). Skeletal sex and gender in Merovingian mortuary archaeology. Antiquity, 74, 632-639.

16. Fairgrieve S.I. (2008). Forensic Cremation: Recovery and Analysis. Taylor \& Francis Group, Boca Raton.

17. Garvin H.M., Passalacqua N.V., Uhl N.M., Gipson D.R., Overbury R.S., Cabo L.L. (2012). Developments in Forensic Anthropology: Age-at-Death Estimation. In: Dirkmaat D. (ed.). A Companion to Forensic Anthropology. Blackwell Publishing, Malden, Oxford, 202-223.

18. Gejvall N.G. (1969). Cremations. In: Brothwell D., Higgs E. (eds.). Science in Archaeology: A Survey of Progress and Research. Thames and Hudson, London, 468-479.

19. Gonçalves D.M.S. (2011). Cremains: The Value of Quantitative Analysis for the Bioanthropological Research of Burned Human Skeletal Remains (Doctoral Dissertation). Universidade de Coimbra [Last accessed 22 November 2014]. Available from: https://estudogeral.sib.uc.pt/handle/10316/18213.

20. Gonçalves D. (2011). The reliability of osteometric techniques for the sex determination of burned human skeletal remains. HOMO - Journal of Comparative Human Biology, 62, 351-358.

21. Gonçalves D., Thompson T.J.U., Cunha E. (2011). Implications of heat-induced changes in bone on the interpretation of funerary behaviour and practice. Journal of Archaeological Science, 38, 1308-1313. 
22. Gonçalves D., Thompson T. J. U., Cunha E. (2013). Osteometric sex determination of burned skeletal remains. Journal of Forensic and Legal Medicine, 20, 906-911.

23. Guy H., Masset C., Baud C.A. (1997). Infant taphonomy. International Journal of Osteoarchaeology, 7, 221-229.

24. Heapost L. (2006). The population of the SE corner of Estonia at the end of the Iron Age and the Middle Ages. Acta Medica Lituanica, 13, 109-114.

25. Henneberg M. (1976). Reproductive Possibilities and Estimations of the Biological Dynamics of Earlier Human Populations. Journal of Human Evolution, $5,41-48$.

26. Hiller J.C., Thompson T.J., Evison M.P., Chamberlain A.T., Wess T.J. (2003). Bone mineral change during experimental heating: an X-ray scattering investigation. Biomaterials, 24, 5091-5097.

27. Holck P. (1986). Cremated bones: A Medical-Anthropological Study of an Archaeological Material on Cremation Burials (=Antropologiske skrifter, 1). Anatomical Institute, University of Oslo, Oslo.

28. Jackes M. (2011). Representativeness and Bias in Skeletal Samples. In: Agarwal S.C., Glencross B.A. (eds.). Social Bioarchaeology. Wiley-Blackwell, Chichester, 107-146.

29. Jankauskas R. (2002). Anthropology of the Iron Age inhabitants of Lithuania. In: Bennike P., Bodszár É.B., Susanne C. (eds.). Ecological Aspects of Past Human Settlements in Europe. Biennial Books of EAA, 2. Eötvös University Press, Budapest, 129-142.

30. Kamp K.A. (2001). Where Have All the Children Gone?: The Archaeology of Childhood. Journal of Archaeological Method and Theory, 8, 1-34.

31. Kurila L. (2009). The Social Organisation in East Lithuania in the 3rd12th Centuries (on the Basis of the Mortuary Record) (Summary of Doctoral Dissertation). Vilnius University [Last accessed 22 November 2014]. Available from: <http://vddb.library.lt/fedora/get/LT-eLABa-0001:E.02 200 9 D_20091109_151308-59594/DS.005.1.01.ETD>.

32. Kurila L. The Accuracy of the Osteological Sexing of Cremated Human Remains: A Test Based on Grave Goods from East Lithuanian Barrows. Collegium Antropologicum. In press.

33. Lewis M.E. (2007). The Bioarchaeology of Children: Perspectives from Biological and Forensic Anthropology. Cambridge University Press, Cambridge.

34. Lorimer F. (1954). Culture and Human Fertility. A Study on the Relation of Cultural Conditions to Fertility in Non-industrial and Transitional Societies. Unesco, Paris.

35. Lucy S. (1994). Children in Early Medieval Cemeteries. Archaeological Review from Cambridge, 13, 21-34.

36. Lucy S.J. (1997). Housewives, warriors and slaves? Sex and gender in AngloSaxon burials. In: Moore J., Scott E. (eds.). Invisible people and processes: 
Writing gender and childhood into European archaeology. Leicester University Press, London, New York, 150-168.

37. Martrille L., Ubelaker D.H., Cattaneo C., Seguret F., Tremblay M., Baccino E. (2007). Comparison of four skeletal methods for the estimation of age at death on white and black adults. Journal of Forensic Sciences, 52, 302-307.

38. Mays S., Cox M. (2000). Sex determination in skeletal remains. In: Cox M., Mays S. (eds.). Human Osteology: In Archaeology and Forensic Science. Cambridge University Press, Cambridge, 117-130.

39. McKinley J.I. (2000). The analysis of cremated bone. In: Cox M., Mays S. (eds.). Human Osteology: In Archaeology and Forensic Science. Cambridge University Press, Cambridge, 403-421.

40. Meindl R.S., Lovejoy C.O. (1985). Ectocranial suture closure: A revised method for the determination of skeletal age at death based on the lateral-anterior sutures. American Journal of Physiscal Anthropology, 68, 57-66.

41. Meindl R.S., Lovejoy C.O., Mensforth R.P., Don Carlos L. (1985). Accuracy and direction of error in the sexing of the skeleton: Implications for paleodemography. American Journal of Physical Anthropology, 68, 79-85.

42. Rösing F.W., Jankauskas R. (1997). Infant deficit in pre-modern burial sites. In: Thetloff M. (ed.). The 8th Tartu International Anthropological Conference. 12-16 October 1997, Tartu, Estonia. Dedicated to the 100th Birth Anniversary of Prof. Juhan Aul. Abstracts. University of Tartu, Centre for Physical Anthropology, Tartu, 50-52.

43. Rösing F.W., Kvaal S.I. (1998). Dental Age in Adults - A Review of Estimation Methods. In: Alt K.W., Rösing F.W., Teschler-Nicola M. (eds.). Dental Anthropology: Fundamentals, Limits, and Prospects. Springer-Verlag, Wien, New York, 442-468.

44. Rudovica V., Viksna A., Zariņa G., Melne I. (2009). An Insight into the Bioarchaeology of the Medieval Inhabitants of Veselava. Archaeologia Baltica, 12, 112-121.

45. Saunders S.R. (2008). Juvenile Skeletons and Growth-Related Studies. In: Katzenberg M.A., Saunders S. R. (eds.). Biological Anthropology of the Human Skeleton. 2nd ed. Wiley-Liss, New York, 117-148.

46. Schmidt C.W., Symes S.A. (eds.) (2008). The Analysis of Burned Human Remains. Academic Press, London.

47. Shipman P., Foster G., Schoeninger M. (1984). Burnt Bones and Teeth: an Experimental Study of Color, Morphology, Crystal Structure and Shrinkage. Journal of Archaeological Science, 11, 307-225.

48. Snodgrass J.J. (2004). Sex Differences and Aging of the Vertebral Column. Journal of Forensic Sciences, 49, 458-463.

49. Sørensen M.L.S. (2000). Gender Archaeology. Polity Press, Cambridge, Maldon. 
50. Stiner M.C., Kuhn S.L., Weiner S., Bar-Yosef O. (1995). Differential Burning, Recrystallization, and Fragmentation of Archaeological Bone. Journal of Archaeological Science, 22, 223-237.

51. Thompson T.J.U. (2005). Heat-induced Dimensional Changes in Bone and their Consequences for Forensic Anthropology. Journal of Forensic Sciences, 50, 1-8.

52. Ubelaker D.H. (1989). Human Skeletal Remains: Excavation, Analysis, Interpretation. 2nd ed. (=Manuals on Archeology, 2). Taraxacum, Washington.

53. Ubelaker D.H. (2009). The forensic evaluation of burned skeletal remains: A synthesis. Forensic Science International, 183, 1-5.

54. Van Deest, T.L, Murad T.A., Bartelink E.J. (2011). A Re-examination of Cremains Weight: Sex and Age Variation in a Northern California Sample. Journal of Forensic Sciences, 56, 344-349.

55. Van Vark, G.N. (1975). The Investigation of Human Cremated Skeletal Material by Multivariate Statistical Methods, II. Measures. Ossa, 2, 47-68.

56. Walker P.L. (1995). Problems of Preservation and Sexism in Sexing: Some Lessons from Historical Collections for Palaeodemographers. In: Saunders S.R., Herring A. (eds). Grave Reflections. Portraying the Past through Cemetery Studies. Canadian Scholars' Press, Toronto, 31-47.

57. Warren M.W., Maples W.R. (1997). The anthropometry of contemporary commercial cremation. Journal of Forensic Sciences, 42, 417-423.

58. Weglian E. (2001). Grave Goods Do Not a Gender Make: A Case Study from Singen am Hohentwiel, Germany. In: Arnold B., Wicker N.L. (eds.). Gender and the Archaeology of Death. AltaMira Press, Walnut Creek, 137-155.

59. Weise S., Boldsen J.L. (2007). 'Dangerous fertile ages' for women: A universal Medieval pattern? American Journal of Physical Anthropology, 132, 246.

60. White T.D., Black M.T., Folkens P.A. (2011). Human Osteology. 3rd ed. Elsevier Academic Press, Burlington.

61. Zarina G. (2006). The main trends in the palaeodemography of the 7 th-18th century population of Latvia. Anthropologischer Anzeiger, 64, 189-202.

62. Zaringa G. (2010). The Social Status of Women in Latvia in the 7th-13th Centuries, in the Light of Palaeodemographic Data. Estonian Journal of Archaeology, $14,56-71$.

\section{Address for correspondence:}

Laurynas Kurila

Lithuanian Institute of History, Department of Archaeology

Kražių st. 5, LT-01108 Vilnius

Lithuania

E-mail: kurila@istorija.lt 